\title{
Profile Characteristics of Listeners in Relation to their Extent of Participation in Sangham Community Radio Programmes
}

\author{
K. Aruna*, V. Sudha Rani and A. Sailaja \\ Department of Agricultural Extension, PJTSAU, Hyderabad, Telangana - 500032, India \\ *Corresponding author
}

A B S T R A C T

\begin{tabular}{|l|}
\hline Ke y w o r d s \\
Community radio, \\
$\begin{array}{l}\text { Participation, } \\
\text { Respondents }\end{array}$ \\
\hline Article Info \\
\hline $\begin{array}{l}\text { Accepted: } \\
18 \text { April } 2018 \\
\text { Available Online: } \\
10 \text { May } 2018\end{array}$ \\
\hline
\end{tabular}

\section{Introduction}

A community radio station is one that is operated in the community, for the community, about the community and by the community. Community Radio will prove most effective as it can easily cover a wider range of areas as well as diversified audience.

Besides, experiments with community radio in many parts of India and abroad have proved it to be the cheapest and the strongest medium for fulfilling communication gap between the community and the Government. It is one of the cheapest mode of mass media, can reach the masses against the barriers like illiteracy, poverty and space limit and can bring social change.
The research study conducted in Medak district during 2009-10, involving 120 from selected twelve villages, revealed that 30.83, 20.00,17.50, 16.67 and

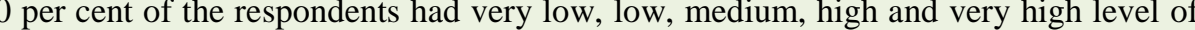
respondents participation of listeners (at 5 percent level of probability) while age, experience in farming (at 5 percent level of probability) and socio-politico participation (at 1 percent level of probability) were negatively and significantly correlated. 
The research study was conducted in Medak district during 2009-10. The Sangham Community Radio covers 4 mandals in Medak district namely Zaheerabad, Jharasangam, Raikode and Nyalkal. From each mandal, three villages were selected at random by following sequential systematic random sampling method. Thus a total of twelve villages were selected for the study. Ten respondents from each village were selected randomly using lottery method, thus making a total of 120 respondents. The profile characteristics of respondents, viz., age, education, occupation, land holding, experience in farming, house-hold, utilization of information sources, socio-politico participation, time spent in house hold activities and traditional media exposure were undertaken for the study. The data were collected by interviewing, the respondents with the help of a pre-tested structured interview schedule developed for the purpose. The data collected from the respondents was scored, tabulated and analyzed by using suitable statistical tools such as frequency and percentage, arithmetic mean, class interval and correlation coefficient.

Correlation coefficient: This measure was used to find the relation between the scores of independent variable $(\mathrm{x})$ and the scores of dependent variable (y) of the study.

$$
\mathrm{r}=\frac{\sum x y-\frac{\Sigma(x) \Sigma(y)}{n}}{\sqrt{\left[\sum x^{2}-\frac{(\Sigma x)^{2}}{n}\right]\left[\sum y^{2}-\frac{(\Sigma y)^{2}}{n}\right]}}
$$

Where

$\mathrm{r}=$ Co-efficient of correlation between $\mathrm{x}$ and $\mathrm{y}$

$\Sigma x=$ Sum of scores of variable $\mathrm{x}$

$\Sigma y=$ Sum of scores of variable $y$

$\Sigma \mathrm{x}^{2}=$ Sum of squares of $\mathrm{x}$ variable
$\Sigma y^{2}=$ Sum of squares of y variable

$(\Sigma \mathrm{x})^{2}=$ Square of sum of variable $\mathrm{x}$

$(\Sigma y)^{2}=$ Square of sum of variable $y$

$\Sigma x y=$ Sum of product of variable $\mathrm{x}$ and $\mathrm{y}$

$\mathrm{n}=$ Size of sample

Finally, the appropriate inferences were drawn at each level of interventions to arrive at the final results.

\section{Results and Discussion}

It was observed from Table 1 that 30.83 per cent of the respondents had very low level of extent of participation whereas $20.00,17.50$, 16.67 and 15.00 per cent of the respondents had low, medium, high and very high level of extent of participation respectively. The reason for having very low level of extent of participation is that may be due to majority of the respondents main occupation is cultivation and are small, marginal and landless and are women. So, they spend most of the time in farm activities and house hold activities. Illiteracy among the respondents also a problem for them to participate in development of the programmes. Probably even low remuneration and own transport arrangements may be other reasons resulting in very low participation in community radio programmes.

Among the variables under study, age was positively and significantly correlated with extent of participation of respondents and while age, experience in farming and sociopolitico participation were negatively and significantly correlated.

As education of the respondents increases their extent of participation also increases, respondents who were having education they participated effectively at all the stages of development of community radio progrmmes than illiterates (Table 2). 
Table.1 Extent of participation by community radio listeners in the community radio programmes

\begin{tabular}{|c|l|l|l|}
\hline S. No & Extent of participation & Frequency & Percentage \\
\hline 1. & Very low & 37 & 30.83 \\
\hline 2 & Low & 24 & 20.00 \\
\hline 3 & Medium & 21 & 17.50 \\
\hline 4 & High & 20 & 16.67 \\
\hline 5 & Very high & 18 & 15.00 \\
\hline & Total & 120 & 100.00 \\
\hline
\end{tabular}

$$
(\mathrm{n}=120)
$$

Table.2 Relationship between profile characteristics and extent of participation of respondents

\begin{tabular}{|c|c|c|c|}
\hline $\begin{array}{l}\text { S. } \\
\text { No }\end{array}$ & Variable & Independent variables & $\begin{array}{l}\text { Correlation } \\
\text { coefficient (r) }\end{array}$ \\
\hline 1. & $\mathrm{X} 1$ & Age & -0.1799 \\
\hline 2. & $\mathrm{X} 2$ & Education & $0.1828^{*}$ \\
\hline \multirow[t]{3}{*}{3.} & $\mathrm{X} 3$ & Occupation & $0.0938^{\mathrm{NS}}$ \\
\hline & $\mathrm{X} 3 \mathrm{a}$ & Primary occupation & $0.1342^{\mathrm{NS}}$ \\
\hline & $\mathrm{X} 3 \mathrm{~b}$ & Primary + Secondary occupation & $-0.1477^{\mathrm{NS}}$ \\
\hline 4. & $\mathrm{X} 4$ & Land holding & $0.1489^{\mathrm{NS}}$ \\
\hline 5. & $\mathrm{X} 5$ & Experience in farming & -0.1914 \\
\hline 6. & X6 & House hold & $-0.1526^{\mathrm{NS}}$ \\
\hline 7. & $\mathrm{X} 7$ & Utilization of information sources & $0.0474^{\mathrm{NS}}$ \\
\hline 8. & $\mathrm{X} 8$ & Socio-politico participation & $-0.2372^{*}$ \\
\hline \multirow[t]{4}{*}{9.} & $X 9 a$ & Time spent in house hold activities & $-0.0455^{\mathrm{NS}}$ \\
\hline & $\mathrm{X} 9 \mathrm{~b}$ & Time spent in farm activities & $-0.0563^{\mathrm{NS}}$ \\
\hline & $\mathrm{X} 9 \mathrm{c}$ & Time spent in economic activities & $0.0713^{\mathrm{NS}}$ \\
\hline & X9d & Leisure time & $-0.0389^{\mathrm{NS}}$ \\
\hline 10. & $\mathrm{X} 10$ & Traditional media exposure & -0.1858 \\
\hline
\end{tabular}

* Note: Significant at 5 per cent of level of significance

** Note: Significant at 1 per cent of level of significance NS Non - significance

Probably those who are literate could able to read and rehearse the programme content before recording. Therefore, education of the respondents was positively correlated with the extent of participation, as education increases their extent of participation also increases. Age of the respondents had negative and significant relationship with extent of participation of respondents. This may be due to majority of young age respondents are more active and interested to participate in community radio programmes than middle and old age respondents.

Experience in farming of the respondents had negative and significant relationship with extent of participation of respondents. more experienced farmers may be busily engaged in farming activities than low experienced farmers. And also young farmers found to participate more in community radio programmes. 
Socio-politico participation of the respondents negatively correlated with the extent of participation of the respondents. Probably the reason for this may be members of sociopolitical organizations may not have time to participate in other activities.

Profile characteristics of respondents in relation to their extent of participation in community radio programmes indicted that among the variables under study, education of the respondents was found to be positively and significantly correlated with extent of participation while age, experience in farming and socio-politico participation were negatively and exhibit significantly contributed towards the extent of participation of respondents. Findings of the study may be utilized by the extension agencies, policy makers, non-Government organizations and other similar organizations for community mobilization. This offers tremendous opportunity for use of electronic media in disseminating information. So, community radio has been acclaimed to be the most effective and cheapest media for diffusing the scientific knowledge to masses.

\section{References}

Sekar V and Perumal G 1988 Awareness and participation of extension personnel in farm broadcast programmes. Indian Journal of Extension Education 24(1\&2): 52-54.

Weerapong Polnigngit 2006 Participation in community radio in Thailand: crossing the Thai - Laotian Border. Pp. 125.

Weerapong Polnigongit 2004 Participation in community radio in Thailand: the case study of Mukdahan province's community enterprise radio station. Pp. 135.

\section{How to cite this article:}

Aruna, K., V. Sudha Rani and Sailaja, A. 2018. Profile Characteristics of Listeners in Relation to their Extent of Participation in Sangham Community Radio Programmes. Int.J.Curr.Microbiol.App.Sci. 7(05): 2185-2188. doi: https://doi.org/10.20546/ijcmas.2018.705.254 